\title{
Analgesic potential of dichloromethane leaf extracts of Eucalyptus globulus (Labill) and Senna didymobotrya (Fresenius) in mice models
}

\author{
Joseph Kiambi Mworia ${ }^{1^{*}}$, Cromwell Mwiti Kibiti $^{2}$, Joseph JN Ngeranwa $^{1(}$, Mathew Piero Ngugi $^{1}{ }^{(}$ \\ ${ }^{1}$ Department of Biochemistry, Microbiology and Biotechnology, Kenyatta University, P. O Box 43844-00100, Nairobi, Kenya \\ ${ }^{2}$ Department of Pure and Applied Sciences, Technical University of Mombasa, P.O Box 90420-80100, Mombasa, Kenya
}

\section{A R T I C L E I N F O}

Article Type:

Original Article

\section{Article History:}

Received: 10 January 2020

Accepted: 18 May 2020

\section{Keywords:}

Eucalyptus globulus

Senna didymobotrya

Pain

Phytochemicals

Formalin test

\begin{abstract}
A B S T R A C T
Introduction: Pain is managed using conventional drugs like paracetamol, aspirin and diclofenac among others. Synthetic drugs have many side effects. This study aimed at evaluating the analgesic potential of the dichloromethane leaf extracts of Eucalyptus globulus and Senna didymobotrya in mice.

Methods: The dichloromethane leaf extracts of E. globulus and S. didymobotrya were subjected to quantitative phytochemical analysis using gas chromatography-mass spectrophotometry (GC-MS). In vivo analgesic evaluation comprised of nine groups of animals (Swiss albino mice): normal, positive, negative control and six experimental groups that received 25, 50, 100, 150,200 and $250 \mathrm{mg} / \mathrm{kg}$ body weight of each plant extract intraperitoneally. Thirty minutes later, they were injected with $0.01 \mathrm{~mL}$ of $2.5 \%$ formalin. The animals in positive control group were administered diclofenac $(15 \mathrm{mg} / \mathrm{kg})$ and formalin, the normal control mice received $3 \%$ dimethyl sulfoxide (DMSO) in normal saline, while the negative group received DMSO in normal saline and formalin. All the doses were administered intraperitoneally. The duration of shaking and licking of the injected paw was scored and analyzed.

Results: The analysis revealed that E. globulus contained alpha-pinenes, endo-fenchol, a-eudesmol, myrcene, camphene, alpha-phellandrene, limonene, and camphor while $S$. dymobotrya possessed camphene, alpha-phellandrene, limonene, and camphor. In the late phase, E. globulus at the doses of 25, 50, 100, 150, 200 and $250 \mathrm{mg} / \mathrm{kg}$ reduced the paw licking time by $34.03 \%, 60.79 \%, 84.33 \%, 90.65 \%, 94.49 \%, 98.52 \%$, respectively while $S$. didymobotrya extract reduced the paw licking time by $26.48 \%, 32.96 \%, 87.04 \%, 91.27 \%, 93.40 \%, 90.97 \%$, and $96.82 \%$, respectively.

Conclusion: The results of this study validate and support the traditional uses of these plants as analgesics.
\end{abstract}

Implication for health policy/practice/research/medical education:

The leaf extracts of Eucalyptus globulus and Senna didymobotrya possess analgesic activity in mice formalin model that might contribute to the development of alternative drugs for management of pain.

Please cite this paper as: Joseph KM, Cromwell MK, Joseph NN, Mathew PN. Analgesic potential of dichloromethane leaf extracts of Eucalyptus globulus (Labill) and Senna didymobotrya (Fresenius) in mice models. J Herbmed Pharmacol. 2020;9(4):391-399. doi: $10.34172 /$ jhp.2020.49.

\section{Introduction}

Pain is an unpleasant sensory affliction and emotional experience associated with actual or potential tissue damage (1). Pain serves as an instant warning to the nervous system to commence a motor response thus minimizing physical damage (2). Insufficient pain relief is a problem globally (3). In pain management, nonsteroidal anti-inflammatory drugs (NSAIDs) are highly prescribed (4). However, these drugs have many side effects such as gastrointestinal complications namely peptic ulcers, bleeding, and mental dependence. Hence, their clinical uses have been limited in pain management (5). Selective 
cyclooxygenase-2 inhibitors have some benefits in preventing such side effects, while the risk of cardiovascular adverse effects demands important consideration (6). Narcotics are also used in pain management (7). Narcotics refer to opium, opium derivatives, and their fully synthetic or semi-synthetic substitutes, including leaf of cocoa and cocaine (8).

In Kenya, Eucalyptus globulus was introduced in 1902 for use as fuel wood for the Kenya-Uganda railway. Junevile leaves of E. globulus are opposite, cordate-ovate, sessile and covered with bluish-white bloom. Adult leaves are lanceolate, alternate, 1-2 inches broad and 6-12 inches long (9). E. globulus is used as antiseptic, deodorant, astringent, anthelmintic, expectorant, inhalant, diaphoretic, insect repellant, sedative, rubefacient, vermifuge and suppurative (10). Besides, E. globulus is used in the management of abscess, asthma, burns, sore throat, bronchitis, cancer, cough, diphtheria, diabetes, arthritis, malaria, dyspepsia, dysentery, miasma, boils, tuberculosis, spasms, wounds, worms and vaginitis (11-13).

Senna didymobotrya is a flowering plant that belongs to the legume family. The plant grows to a maximum height of about $30-90 \mathrm{~cm}$. It is found across the country in several types of the habitat. The root extracts of S. didymobotrya are utilized in the management of intestinal worms and malaria (14).

Pain is managed using medicinal plants such as Artemisia dracunculus (15), Acacia mellifera, Carissa spinarum (Linn) (16), Harrisonia abyssinica (17), among others. E. globulus and S. didymobotrya are in traditional use in the management of pain by the people of Embu county. However, there are no scientific data to support this biological activity. Therefore, this study was designed to determine the chemical constituents and in vivo analgesic potential of dichloromethane leaf extracts of $E$. globulus and $S$. didymobotrya in mice models.

\section{Materials and Methods}

Based on the literature review on ethno-medicinal uses of these plants, leaves from each of these plants were harvested from Embu county, Kenya. The plant samples were put in Khaki bags and then transported to Kenyatta University. Further processing of the plant samples was carried out in the Department of Biochemistry, Microbiology, and Biotechnology. The leaf samples were identified and taxonomically assigned voucher specimen numbers by an acknowledged taxonomist. E. globulus and $S$. didymobotrya were assigned voucher specimen numbers "JKM001" and "JKM002" respectively. The samples were deposited at Kenyatta University Herbarium for future reference.

The plant leaf samples were air-dried at $25^{\circ} \mathrm{C}$ for two weeks and then ground into a homogenous fine powder. The powder of each sample was kept at room temperature in well-sealed and labeled airtight khaki papers until use in extraction. Five-hundred grams of each plant sample was weighed separately and then put into well-labeled conical flasks, separately. Two liters of dichloromethane (DCM) were put into each conical flask, corked and then let to stand for one day. The mixtures were then filtered separately using Whatman number 1 filter papers. To each of the remnants, $1 \mathrm{~L}$ of DCM was added and left to stand for 24 hours. This was followed by a second filtration. This procedure was repeated until the solvent appeared clear. The concentration of each extract was carried out using a rotary evaporator at $40^{\circ} \mathrm{C}$. The concentrated extracts were then separately put in clean open beakers to permit the evaporation of the remaining solvents. The extracts obtained were stored at $-4^{\circ} \mathrm{C}$ until use (18).

Gas chromatography-mass spectrophotometry (GC-MS) analysis

Agilent Gas Chromatograph 7890A/5975C Mass Spectrometer in full scan mode was used to analyze the samples with the following conditions; gas chromatography column "HP-5 MS low bleed capillary column" ( $0.25 \mu \mathrm{m}, 30 \mathrm{~m}$ by $0.25 \mathrm{~mm}$ i.d) (J and W, Folsom, California, United States of America), flow rate (Helium) "constant flow mode, $1.25 \mathrm{~mL} / \mathrm{min}$ ", injection split mode, oven temperature of $35^{\circ} \mathrm{C}$ for the initial 5 minutes and then raised by $10^{\circ} \mathrm{C}$ per minute to $28^{\circ} \mathrm{C}$ for 10.5 minutes and run time of 70 minutes.

For analysis, a protocol was used, which was reviewed by the Principal Scientist, and the Head of the Department of Behavioral and Chemical Ecology in the International Centre of Insect Physiology and Ecology (ICIPE), Prof. Baldwyn Torto. A mass of $1.2 \mathrm{mg}$ of DCM leaf extract of E. globulus and $1.1 \mathrm{mg}$ of $S$. didymobotrya were diluted by partitioning between methanol and hexane. This was followed by vortexes and centrifugation. Bypassing through anhydrous $\mathrm{Na}_{2} \mathrm{SO}_{4}$, the hexane layer was dried and analyzed using GC-MS. Authentic serial dilutions of 1,8-cineole $99 \%$ as standard (Gillingham, Dorset, England) (50, 150, 250, 350 and $550 \mathrm{ng} / \mu \mathrm{L})$ were prepared and analyzed using GC-MS. The peak areas were used for quantification purposes.

\section{Experimental animals}

Swissalbino miceofboth sexesaged between 2-3 monthsand weighing approximately $20 \mathrm{~g}$ were used to assess analgesic activities of the two DCM leaf extracts. The approval for experimentation of animals was obtained from the National Commission for Science, Technology, and Innovation (Reference number NACOSTI/P/16/6765/14525). The animals were taken care of, and handled as per Kenyatta University ethical guidelines and procedures for handling experimentation animals. Mice were selected 24 hours before experimentation based on their normal response to sensorimotor testing. The sensorimotor test was done by holding the mice in a fully extended and inverted position 
one hour after administration of controls and dosages $(19,20)$.

\section{Experimental design}

A completely randomized experimental design was adopted in this study. Swiss albino mice were randomly allocated nine groups of 5 mice and treated as follows; group 1 (normal control) comprised mice that received intraperitoneally 3\% DMSO. Group 2 (negative control) received $3 \%$ DMSO and then pain was induced after 30 minutes by injection of $0.01 \mathrm{~mL}$ of $2.5 \%$ formalin. Group 3 (positive control), received $0.1 \mathrm{~mL}$ of diclofenac sodium at a dose of $15 \mathrm{mg} / \mathrm{kg}$ body weight and after 30 minutes were administered with $0.01 \mathrm{~mL}$ of $2.5 \%$ formalin to induce pain.

Groups 4, 5, 6, 7, 8 and 9 (5 mice/group) received 25 $\mathrm{mg} / \mathrm{kg}, 50 \mathrm{mg} / \mathrm{kg}, 100 \mathrm{mg} / \mathrm{kg}, 150 \mathrm{mg} / \mathrm{kg}, 200 \mathrm{mg} / \mathrm{kg}$ and $250 \mathrm{mg} / \mathrm{kg}$ DCM leaf extract in 3\% DMSO respectively. After 30 minutes, pain was induced through injection of the left hind paw tissue with $0.01 \mathrm{~mL}$ of $2.5 \%$ formalin. Table 1 summarizes this experimental design.

The formalin-induced pain was carried out by a previously described method (21), where all the animals received $0.1 \mathrm{~mL}$ of treatments intraperitoneally and 30 minutes later with $0.01 \mathrm{~mL}$ injection of $2.5 \%$ formalin in the left hind paw to induce pain. The time taken on licking, shaking, biting or lifting of the injected paw was scored and recorded (22). The Swiss albino mice were placed inside a transparent plexiglass chamber with a mirror put at the side of the chamber to provide a clear observation of the pain response. Two phases of intensive pain were observed and recorded separately (the early phase of 1-5 minutes and late phase of 15-30 minutes). The percentage of pain inhibition was computed using the following formula.

Percentage pain inhibition $=\frac{C-T}{C} \times 100$

Where, $\mathrm{C}=$ Vehicle control group value for each phase

Table 1. Grouping of the mice for evaluation of antinociceptive effects of the extracts

\begin{tabular}{ll}
\hline Animal group & Treatment \\
\hline I & DMSO only \\
II & Formalin + DMSO \\
III & Formalin $+15 \mathrm{mg} / \mathrm{kg}$ diclofenac \\
IV & Formalin $+25 \mathrm{mg} / \mathrm{kg}$ extract \\
V & Formalin $+50 \mathrm{mg} / \mathrm{kg}$ extract \\
VI & Formalin $+100 \mathrm{mg} / \mathrm{kg}$ extract \\
VII & Formalin $+150 \mathrm{mg} / \mathrm{kg}$ extract \\
VIII & Formalin $+200 \mathrm{mg} / \mathrm{kg}$ extract \\
IX & Formalin $+250 \mathrm{mg} / \mathrm{kg}$ extract \\
\hline
\end{tabular}

$\mathrm{T}=$ Treated group value for each phase.

\section{Statistical analysis}

Data on pain was entered in a Microsoft Excel broadsheet and then transferred to Minitab statistical software (version 17.0) for statistical analysis. Descriptive statistics (mean \pm SEM) were computed. One-way analysis of variance was employed to analyze for statistical variation among various sets of treatment groups followed by Tukey's post hoc test for mean separations and comparisons. Analgesic activity of the two plant extracts was compared using unpaired $t$ test. The level of significance was set at $99.5 \%(P \leq 0.005)$.

\section{Results}

GC-MS results of E. globulus (Labill) and S. didymobotrya (Fresenius)

The GC-MS results revealed that these plants were endowed with several bioactive agents that possessed analgesic activity (Table 2). Representative total ion chromatogram of the DCM leaf extracts of E. globulus and S. didymobotrya with their retention times are respectively presented in Figures 1 and 2.

The molecular and structural formula of compounds identities of DCM leaf extracts of E. globulus and S. didymobotrya are shown in Figure 3.

Analgesic effects of DCM leaf extracts of E. globulus and S. didymobotrya in mice

Two phases were used to assess the antinociceptive activities of DCM leaf extracts of E. globulus and S. didymobotrya on formalin-induced nociception in Swiss albino mice. They included the early phase which lasted between 1-5 minutes and a late phase that lasted between 15-30 minutes after injection of formalin. E. globulus leaf extracts possessed analgesic activity in mice. This was evident by a reduction in paw shaking, licking and lifting time (Table 3).

The Swiss albino mice that received E. globulus extract at the doses of $25,50,100,150,200$ and $250 \mathrm{mg} / \mathrm{kg}$ body weight as well as diclofenac $(15 \mathrm{mg} / \mathrm{kg})$, decreased the paw licking time in the early phase by $8.29 \%, 31.87 \%, 19.84 \%$, $31.71 \%, 29.76 \%, 30.57 \%$, and $31.87 \%$, respectively (Table $3)$. The analgesic activity of E. globulus DCM extract at the six dosages exhibited a significant difference in the early phase $(P<0.005$, Table 3$)$. On the other hand, the analgesic effect of diclofenac was not statistically significant compared with E. globulus at dosages of 50, 150,200 and $250 \mathrm{mg} / \mathrm{kg}$ body weight in the early phase $(P$ $>0.005$, Table 3). The antinociceptive effect of E. globulus extract showed a dose-independent response in the early phase (Table 3).

The mice that were administered with DCM leaf extract of E. globulus at the doses of 25, 50, 100, 150, 200 and 250 $\mathrm{mg} / \mathrm{kg}$ body weight including the diclofenac, reduced the paw licking time by $34.03 \%, 60.79 \%, 84.33 \%$, 90.65\%, 
Table 2. GC-MS results of E. globulus (Labill) and S. didymobotrya (Fresenius) phytocompounds associated with analgesic activity

\begin{tabular}{|c|c|c|c|c|c|}
\hline Compound name & Chemical class & $\begin{array}{c}\text { E. globulus retention } \\
\text { time (min) }\end{array}$ & $\%$ Abundance & $\begin{array}{c}\text { S. didymobotrya } \\
\text { Retention time (min) }\end{array}$ & $\%$ Abundance \\
\hline Endo-fenchol & Terpenoids & 13.25 & 1.15 & - & - \\
\hline$\alpha$-Eudesmol & Terpenoids & 20.64 & 14.81 & - & - \\
\hline Myrcene & Terpenoids & 11.01 & 0.75 & - & - \\
\hline p-Cymene & Terpenoids & 11.64 & 7.81 & - & - \\
\hline Camphene & Terpenoids & 10.11 & 2.01 & 10.11 & 9.11 \\
\hline$\alpha$-Phellandrene & Terpenoids & 11.26 & 12.73 & 11.26 & 3.24 \\
\hline Limonene & Terpenoids & 11.71 & 10.44 & 11.73 & 24.9 \\
\hline$\beta$-Pinene & Terpenoids & 10.70 & 10.68 & 10.72 & 3.85 \\
\hline Camphor & Flavonoids & 13.74 & 4.03 & 13.74 & 34.01 \\
\hline$\alpha$-Pinenes & Terpenoids & 9.78 & 5.73 & 9.80 & 5.47 \\
\hline
\end{tabular}

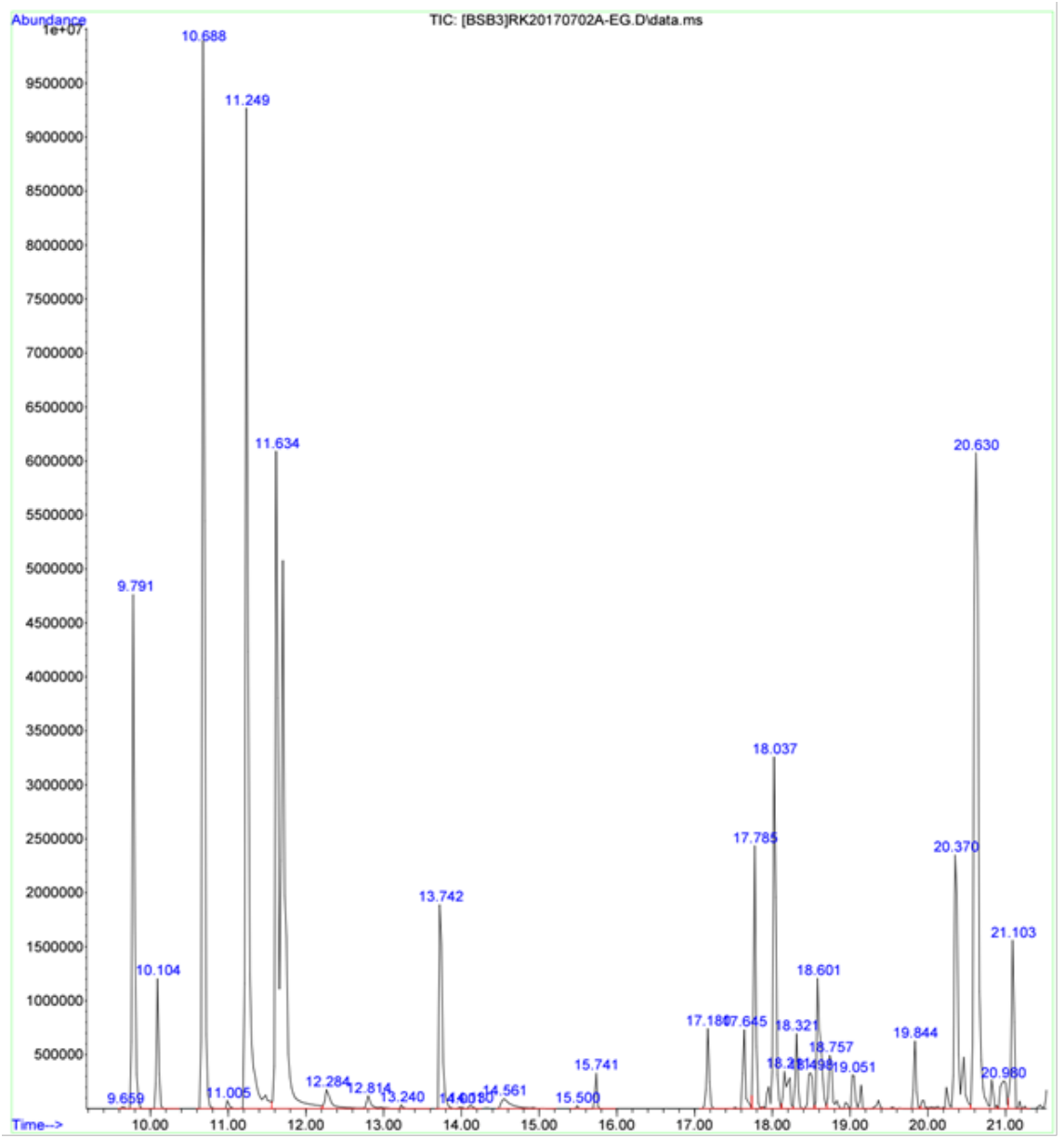

Figure 1. Representative total ion chromatogram of the DCM leaf extract of $E$. globulus with retention time.

94.49\%, 98.52\%, and $98.32 \%$, respectively in the late phase (Table 3). The analgesic activity of the leaf extract at the six dosages revealed a significant difference in the late phase $(P<0.005$; Table 3$)$. In contrast, the analgesic activity of the diclofenac was comparable to that of DCM leaf extract of E. globulus (Labill) at a dose of $250 \mathrm{mg} / \mathrm{kg}$ body weight in the late phase $(P>0.005$; Table 3$)$. The analgesic effect of the leaf extract of E. globulus showed a dose-dependent response in the late phase (Table 3 ).

The analgesic effect of DCM extract of E. globulus at all the six dose levels was significantly effective in the late phase compared to the early phase $(P<0.005)$.

On the other hand, the mice that received DCM leaf extract of $S$. didymobotrya (Fresenius)had reduced 


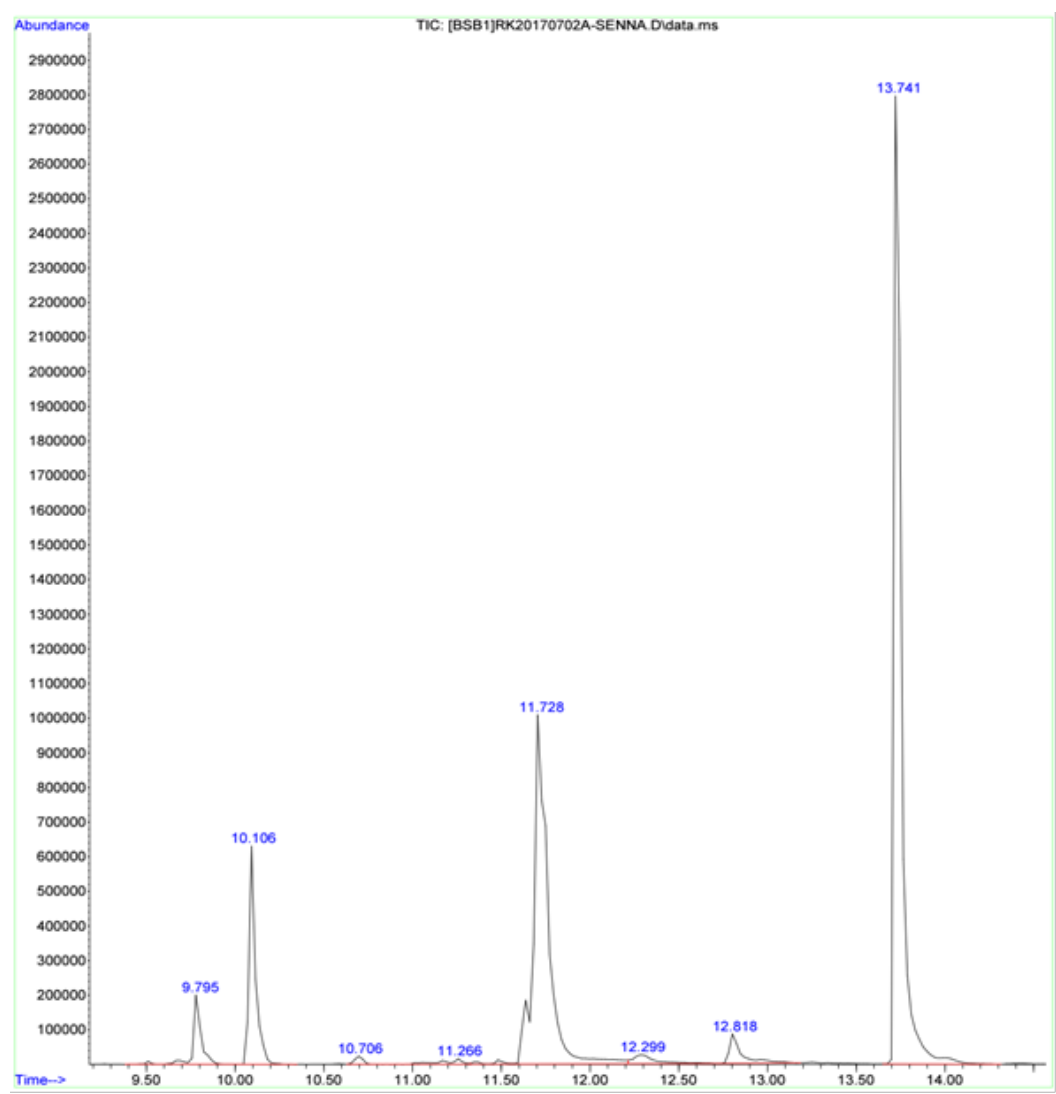

Figure 2. Representative total ion chromatogram of the DCM leaf extract of S. didymobotrya with retention time.

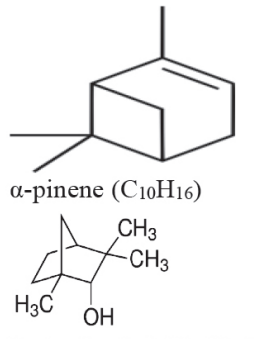

Endo-fenchol $\left(\mathrm{C}_{10} \mathrm{H}_{18} \mathrm{O}\right)$

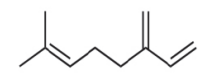

Myrcene $\left(\mathrm{C}_{10} \mathrm{H}_{16}\right)$
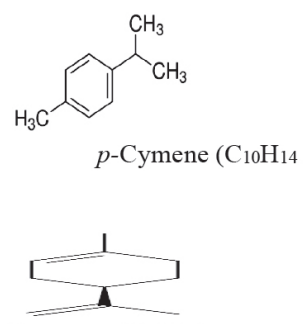

limonene $\left(\mathrm{C}_{10} \mathrm{H}_{16}\right)$

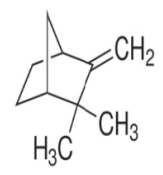

Camphene $\left(\mathrm{C}_{10} \mathrm{H}_{16}\right)$

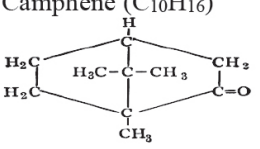

Camphor $\left(\mathrm{C}_{10} \mathrm{H}_{18} \mathrm{O}\right)$

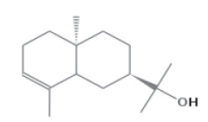

$\alpha$-Eudesmol $\left(\mathrm{C}_{15} \mathrm{H}_{26} \mathrm{O}\right)$

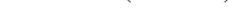

Figure 3. The structural and molecular formula of compounds identified by gas chromatography-mass spectrometry analysis of the DCM leaf extract of $E$. globulus and S. didymobotrya . formalin-induced pain which was evident by reduced paw time licking in the two phases (Table 4). The mice that received DCM extract of $S$. didymobotrya at the doses of $50,100,150,200$ and $250 \mathrm{mg} / \mathrm{kg}$ bw as well as diclofenac (the reference drug) reduced paw licking time in the early phase by $0.43 \%, 1.61 \%, 5.81 \%, 7.20 \%, 7.96 \%$, and $38.17 \%$, respectively (Table 4). However, the plant extract at 25 $\mathrm{mg} / \mathrm{kg}$ body weight dose level did not show significant analgesic effect in the early phase as shown in Figure 3. In the early phase, the analgesic activity of $S$. didymobotrya at the six dose levels revealed significant differences $(P<0.005$; Table 4$)$.

The analgesic effect of the diclofenac was significantly higher compared to that of the DCM extract of $S$. didymobotrya at all dose levels in the early phase $(P<0.005$; Table 4). The antinociceptive effect of $S$. didymobotrya demonstrated a dose-dependent response in the early phase (Table 4). The $S$. didymobotrya extract at the doses of $25,50,100,150,200$ and $250 \mathrm{mg} / \mathrm{kg}$ bw including diclofenac, lowered the paw licking time by $26.48 \%$, $32.96 \%, 87.04 \%, 91.27 \%, 93.40 \%, 90.97 \%$, and $96.82 \%$, respectively in the late phase (Table 4). The analgesic activity of the $S$. didymobotrya extract at the six dose levels was statistically significant in the late phase $(P<0.005$, Table 4). The analgesic effect of diclofenac was significantly 
Table 3. Antinociceptive activity of E. globulus (Labill) dichloromethane (DCM) leaf extract on formalin-induced pain in mice

\begin{tabular}{llll}
\hline Group & Treatment & Early Phase (1-5 min) & Late Phase (15-30 min) \\
\hline Normal control & DMSO only & $0.00 \pm 0.00^{\mathrm{e}}(0.00)$ & $0.00 \pm 0.00^{\mathrm{h}}(0.00)$ \\
\hline Negative control & Formalin + DMSO & $123.00 \pm 1.55^{\mathrm{a}}(100.00)$ & $297.40 \pm 9.58^{\mathrm{a}}(100.00)$ \\
\hline Positive control & Diclofenac $15 \mathrm{mg} / \mathrm{kg} \mathrm{bw}+$ Formalin & $83.80 \pm 1.39^{\mathrm{d}}(31.87)$ & $5.00 \pm 0.89^{\mathrm{g}}(98.32)$ \\
\hline & $25 \mathrm{mg} / \mathrm{kg} \mathrm{bw}+$ Formalin & $112.80 \pm 1.24^{\mathrm{b}}(8.29)$ & $196.20 \pm 1.05^{\mathrm{b}}(34.03)$ \\
\hline & $50 \mathrm{mg} / \mathrm{kg} \mathrm{bw}+$ Formalin & $83.80 \pm 1.62^{\mathrm{d}}(31.87)$ & $116.80 \pm 0.93^{\mathrm{c}}(60.79)$ \\
\hline DCM leaf extract of E. globulus & $100 \mathrm{mg} / \mathrm{kg} \mathrm{bw}+$ Formalin & $98.60 \pm 1.08^{\mathrm{c}}(19.84)$ & $46.60 \pm 0.93^{\mathrm{d}}(84.33)$ \\
& $150 \mathrm{mg} / \mathrm{kg} \mathrm{bw}+$ Formalin & $84.00 \pm 0.55^{\mathrm{d}}(31.71)$ \\
\hline $200 \mathrm{mg} / \mathrm{kg} \mathrm{bw}+$ Formalin & $86.40 \pm 1.96^{\mathrm{d}}(29.76)$ & $16.40 \pm 1.03^{\mathrm{f}}(94.49)$ \\
\hline
\end{tabular}

Values are expressed as mean \pm SEM for 5 mice in each group. Values with the different superscript letters are statistically significant along the same column using one-way ANOVA accompanied by Tukey's post hoc test $(P \leq 0.005)$. The values in brackets represent \% pain inhibition.

Table 4. Analgesic effect of dichloromethane (DCM) leaf extract of S. didymobotrya (Fresenius) on formalin-induced pain in mice

\begin{tabular}{|c|c|c|c|}
\hline Animal Group & Treatments & Early Phase (1-5 min) & Late Phase (15-30 $\mathrm{min})$ \\
\hline Normal control & DMSO only & $0.00 \pm 0.00^{e}(0.00)$ & $0.00 \pm 0.00^{h}(0.00)$ \\
\hline Negative control & Formalin +DMSO & $186.00 \pm 0.01^{\mathrm{a}}(100.00)$ & $321.00 \pm 0.01^{\mathrm{a}}(100.00)$ \\
\hline Positive control & Diclofenac 15 mg/kg bw + Formalin & $115.00 \pm 3.29^{d}(38.17)$ & $10.20 \pm 0.49^{\mathrm{g}}(96.82)$ \\
\hline \multirow{6}{*}{$\begin{array}{l}\text { DCM leaf extract of } S \text {. } \\
\text { didymobotrya }\end{array}$} & $25 \mathrm{mg} / \mathrm{kg}$ bw + Formalin & $189.60 \pm 0.93^{\mathrm{a}}(-1.94)$ & $236.00 \pm 1.70^{b}(26.48)$ \\
\hline & $50 \mathrm{mg} / \mathrm{kg}$ bw + Formalin & $185.20 \pm 1.69^{\mathrm{a}}(0.43)$ & $215.20 \pm 0.97^{c}(32.96)$ \\
\hline & 100 mg/kg bw + Formalin & $183.00 \pm 1.22^{\mathrm{ab}}(1.61)$ & $41.60 \pm 1.8^{\mathrm{d}}(87.04)$ \\
\hline & $150 \mathrm{mg} / \mathrm{kg}$ bw+ Formalin & $175.20 \pm 1.39^{\mathrm{bc}}(5.81)$ & $28.20 \pm 0.97^{e}(91.27)$ \\
\hline & 200 mg/kg bw + Formalin & $172.00 \pm 0.93^{\mathrm{c}}(7.20)$ & $21.20 \pm 1.07^{f}(93.40)$ \\
\hline & $250 \mathrm{mg} / \mathrm{kg}$ bw + Formalin & $171.20 \pm 1.77^{c}(7.96)$ & $29.00 \pm 1.26^{\mathrm{e}}(90.97)$ \\
\hline
\end{tabular}

Values are expressed as mean \pm SEM for 5 mice in each group. Values with the different superscript letters are statistically significant along the same column using one-way ANOVA accompanied by Tukey's post hoc test $(P \leq 0.005)$. The values in brackets represent \% pain inhibition.

higher compared to those of the six of extracts dose levels in the late phase $(P<0.005$, Table 4$)$. The analgesic effect of $S$. didymobotrya had a dose-dependent response in both phases, except the dose of $250 \mathrm{mg} / \mathrm{kg}$ bw dose in the late phase that was not as potent as $200 \mathrm{mg} / \mathrm{kg}$ bw (Table 4). In comparison, the analgesic effect of $S$. didymobotrya DCM leaf extract in the late phase was significantly higher compared to the early phase at the six dose levels tested in mice $(P<0.005$, Table 4$)$.

Comparatively, the analgesic effect of E. globulus DCM extract was significantly higher than that of $S$. didymobotrya DCM extract at all the tested dose levels in the early phase $(P<0.005$, Figure 4$)$.

The analgesic effects of $S$. didymobotrya (Fresenius) and E. globulus DCM leaf extracts demonstrated no significant differences at the doses of 100, 150 and $200 \mathrm{mg} / \mathrm{kg}$ body weight in the late phase $(P>0.005$, Figure 4$)$. On the other hand, the analgesic effect of the DCM extract of $E$. globulus was significantly higher compared to that of $S$. didymobotrya in the late phase the doses of 25, 50 and 250 $\mathrm{mg} / \mathrm{kg}$ body weight $(P<0.005$, Figure 5$)$.

\section{Discussion}

This study aimed at determining the analgesic activity of DCM leaf extracts of E. globulus and S. didymobotrya on formalin-induced nociception in mice. The E. globulus and $S$. didymobotrya leaf extracts showed significant analgesic effects by reducing pain in mice in the early and late phases. The demonstrated effects were both peripheral and central (23). The central analgesic activity could have been due to inhibition of the nociceptive effects of noradrenaline, bradykinin, prostaglandins, adrenaline, adenosine, serotonin, and acetylcholine. On the other hand, the peripheral analgesic effect could be attributed to inhibition of the discharge of endogenous pain mediators like prostaglandin-2 $\left(\mathrm{PGE}_{2)}\right.$ and $\mathrm{PGE}_{2}-\alpha$ in peritoneal fluids including lipoxygenase which triggers the nociceptive neurons (24).

The significant antinociceptive effects of DCM leaf extracts of these plants could be attributed to the existence of analgesic components that acted by blocking the prostaglandin pathways (25). The DCM leaf extracts mechanisms of action can be postulated to be similar to those of NSAIDs like diclofenac and ibuprofen. These 


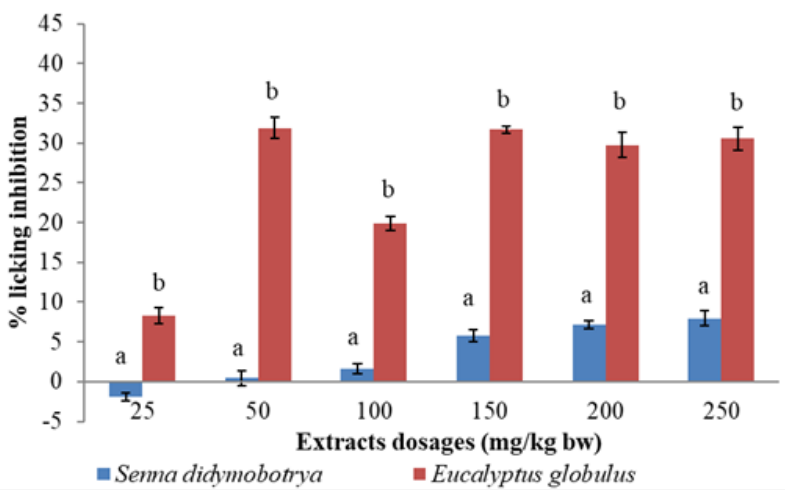

Figure 4. Comparison of antinociceptive activities E. globulus and $S$. didymobotrya dichloromethane leaf extract in the early phase in mice. Means with different letters are significantly different $(P \leq 0.005)$ at the same dose level using the unpaired student $t$ test.

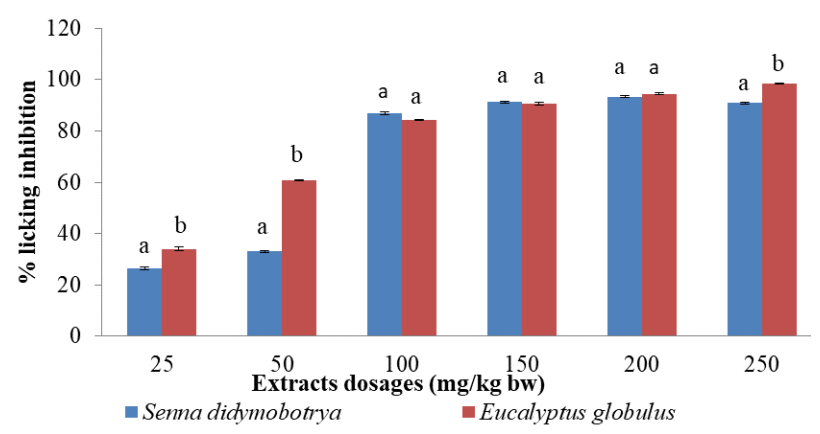

Figure 5. Comparison of antinociceptive activities of E. globulus and $S$. didymobotrya dichloromethane leaf extracts in the late phase in mice. Means with different letters are statistically significant $(P \leq 0.005)$ at the same dose level using the unpaired student $t$ test.

drugs block the synthesis of prostaglandins by truncating the cyclooxygenase-1 pathway (26). This inhibition lowers the peripheral nervous tissue sensitization leading to less nerve stimulation and pain reduction (27). The DCM leaf extracts of the two plants exhibited analgesic effects by decreasing paw licking time in early and late phases on formalin-induced pain in mice (28).

GC-MS results revealed the presence of bioactive phytochemicals that possessed analgesic activity. According to previous study, Aniba canelilla was found to have analgesic effects on the acetic acid-induced writhing, hot plate test and formalin-induced pain at doses of 50, 100 and $200 \mathrm{mg} / \mathrm{kg}$ bw. The study also found that the plant contains essential oils possessed significant analgesic activity (29). Studies by (30), on analgesic activity of p-cymene in glutamate, formalin and capsaicin tests in mice models, showed that this compound possessed analgesic potential. p-Cymene also possesses antinociceptive activity and has been shown to reduce the acetic acid-induced writhing in rodents. Alpha-terpineol is a monoterpenoid alcohol found in the essential oils of several species of Eucalyptus. a-Terpineol on acetic acid, formalin, glutamate-induced pain, and hot plate induced pain (32). The GC-MS analysis of DCM leaf extracts of E. globulus revealed the presence of a-eudesmol, a component of essential oil. A study by (33), on seasonal variation, chemical composition, and analgesic and antimicrobial activities of the essential oil from leaves of Tetradenia riparia in Southern Brazil reported that a-eudesmol reduced acetic acid-induced abdominal writhing in mice.

A study carried out by Radulović et al (34), on the analgesic activity of $F$. ovina using acetic acid abdominal constrictions, hot plate, tail immersion and dynamic hot plate tests in mice at doses 50, 100 and $200 \mathrm{mg} / \mathrm{kg}$ revealed that essential oils of which camphor was a component possessed antinociceptive activity. A review by Nuutinen (35), reported that endo-fenchol is able to induce hyperalgesia in mice. Limonene also a component of essential oils belongs to monoterpenoids. It has been reported by Erasto and Viljoen in their review on biosynthetic, ecological and pharmacological relevance that limonene possessed analgesic activity (36). Studies reported by Paula-Freire et al (37), on antihypernociceptive activity of O. gratissimum essential oil, reported that myrcene at doses of 10,20 and $40 \mathrm{mg} / \mathrm{kg}$ body weight showed significant antinociceptive activity against von Frey and hot plate tests models in mice. Similarly, a study by Shah et al (38), reported that myrcene had antinociceptive potential, by reducing latency time in tail-flick and hot plate test models in rodents.

\section{Conclusion}

In conclusion, the DCM leaf extracts of E. globulus and S. didymobotrya were found to contain bioactive compounds that were able to significantly reduce formalin-induced analgesia in mice. This study validates the traditional use of these plants in the management of pain.

\section{Acknowledgments}

Authors wish to thank Kenyatta University for availing the laboratories for animal breeding and experimentation using their facility and the International Centre of Insect Physiology and Ecology for allowing us uses their laboratory to carry out GC-MS analysis of the plant extracts.

\section{Authors' contributions}

JKM, CMK, JNN and MPN: Designed the project, collected the specimen and performed the experiments, analyzed and data. The first draft was prepared by JKM. All authors read the final version and confirmed it for the publication.

\section{Conflict of interests}

All the listed authors declare no conflicts of interest. 


\section{Ethical considerations}

The approval for experimentation of animals was obtained from the National Commission for Science, Technology and Innovation (Reference Number: NACOSTI/P/16/6765/14525).

\section{Funding/Support}

No funding was received for this study from any funding body.

\section{References}

1. Tracey I, Woolf CJ, Andrews NA. Composite Pain Biomarker signatures for objective assessment and effective treatment. Neuron. 2019;101(5):783-800. doi: 10.1016/j. neuron.2019.02.019.

2. Zussy C, Gómez-Santacana X, Rovira X, De Bundel D, Ferrazzo S, Bosch D, et al. Dynamic modulation of inflammatory pain-related affective and sensory symptoms by optical control of amygdala metabotropic glutamate receptor 4. Mol Psychiatry. 2018;23(3):509-20. doi: 10.1038/ mp.2016.223.

3. Andreu V, Arruebo M. Current progress and challenges of nanoparticle-based therapeutics in pain management. J Control Release. 2018;269:189-213. doi: 10.1016/j. jconrel.2017.11.018.

4. Santos Garcia JB, Lech O, Campos Kraychete D, Rico MA, Hernández-Castro JJ, Colimon F, et al. The role of tramadol in pain management in Latin America: a report by the Change Pain Latin America Advisory Panel. Curr Med Res Opin. 2017;33(9):1615-21. doi: 10.1080/03007995.2017.1354821.

5. Nicholas MK, Asghari A, Sharpe L, Beeston L, Brooker C, Glare P, et al. Reducing the use of opioids by patients with chronic pain: an effectiveness study with longterm follow-up. Pain. 2020;161(3):509-19. doi: 10.1097/j. pain.0000000000001763.

6. Hippisley-Cox J, Coupland C. Risk of myocardial infarction in patients taking cyclo-oxygenase-2 inhibitors or conventional non-steroidal anti-inflammatory drugs: population based nested case-control analysis. BMJ. 2005;330(7504):1366. doi: 10.1136/bmj.330.7504.1366.

7. Cancienne JM, Patel KJ, Browne JA, Werner BC. Narcotic use and total knee arthroplasty. J Arthroplasty. 2018;33(1):113-8. doi: 10.1016/j.arth.2017.08.006.

8. Boehnke KF, Litinas E, Clauw DJ. Medical cannabis use is associated with decreased opiate medication use in a retrospective cross-sectional survey of patients with chronic pain. J Pain. 2016;17(6):739-44. doi: 10.1016/j. jpain.2016.03.002.

9. Mishra AK, Sahu N, Mishra A, Ghosh AK, Jha S, Chattopadhyay P. Phytochemical screening and antioxidant activity of essential oil of Eucalyptus leaf. Pharmacogn J. 2010;2(16):25-8. doi: 10.1016/s0975-3575(10)80045-8.

10. Pan M, Lei Q, Zang N, Zhang H. A strategy based on GCMS/MS, UPLC-MS/MS and virtual molecular docking for analysis and prediction of bioactive compounds in Eucalyptus globulus leaves. Int J Mol Sci. 2019;20(16). doi: 10.3390/ijms20163875.

11. Tabassum N, Hamdani M. Plants used to treat skin diseases. Pharmacogn Rev. 2014;8(15):52-60. doi: 10.4103/09737847.125531.

12. Jouad H, Maghrani M, Hassani RAE, Eddouks M.
Hypoglycemic activity of aqueous extract of Eucalyptus globulus in normal and streptozotocin-induced diabetic rats. J Herbs Spices Med Plants. 2004;10(4):19-28. doi: 10.1300/J044v10n04_03.

13. Mahmoudzadeh-Sagheb H, Heidari Z, Bokaeian M, Moudi B. Antidiabetic effects of Eucalyptus globulus on pancreatic islets: a stereological study. Folia Morphol (Warsz). 2010;69(2):112-8.

14. Alemayehu I, Tadesse S, Mammo F, Kibret B, Endale M. Phytochemical analysis of the roots of Senna didymobotrya. J Med Plant Res. 2015;9(34):900-7. doi: 10.5897/ jmpr2015.5832.

15. de Cássia da Silveira ESR, Lima TC, da Nóbrega FR, de Brito AEM, de Sousa DP. Analgesic-like activity of essential oil constituents: an update. Int J Mol Sci. 2017;18(12). doi: 10.3390/ijms 18122392 .

16. Wambugu SN, Mathiu PM, Gakuya DW, Kanui TI, Kabasa JD, Kiama SG. Medicinal plants used in the management of chronic joint pains in Machakos and Makueni counties, Kenya. J Ethnopharmacol. 2011;137(2):945-55. doi: 10.1016/j.jep.2011.06.038.

17. Koech SC, Sindani AV, Maoga JB, Ouko RO, Njagi NM, Ngugi MP. Anti-pyretic potential of dichloromethanolic root extract of Clutia abyssinica in Wistar albino rats. Med Aromat Plants. 2017;6(1):281. doi: 10.4172/21670412.1000281 .

18. Gaylor MO, Juntunen HL, Hazelwood D, Videau P. Assessment of multiple solvents for extraction and direct GC-MS determination of the phytochemical inventory of Sansevieria extrafoliar nectar droplets. J Chromatogr Sci. 2018;56(4):293-9. doi: 10.1093/chromsci/bmy008.

19. Ramírez-Boix P, Giménez-Llort L. Comorbid sensorimotor and emotional profiles in the forced swim test immobility and predictive value of a single assay in very old female mice. Exp Gerontol. 2019;120:107-12. doi: 10.1016/j. exger.2019.03.004.

20. Bilel S, Tirri M, Arfè R, Ossato A, Trapella C, Serpelloni $\mathrm{G}$, et al. Novel halogenated synthetic cannabinoids impair sensorimotor functions in mice. Neurotoxicology. 2020;76:17-32. doi: 10.1016/j.neuro.2019.10.002.

21. Hunskaar S, Hole K. The formalin test in mice: dissociation between inflammatory and non-inflammatory pain. Pain. 1987;30(1):103-14. doi: 10.1016/0304-3959(87)90088-1.

22. Tjølsen A, Berge OG, Hunskaar S, Rosland JH, Hole K. The formalin test: an evaluation of the method. Pain. 1992;51(1):5-17. doi: 10.1016/0304-3959(92)90003-t.

23. Kamarudin N, Hisamuddin N, Ong HM, Ahmad Azmi AF, Leong SW, Abas F, et al. Analgesic effect of 5-(3,4-Dihydroxyphenyl)-3-hydroxy-1-(2-hydroxyphenyl) penta-2,4-dien-1-one in experimental animal models of nociception. Molecules. 2018;23(9). doi: 10.3390/ molecules23092099.

24. Yan S, Tang J, Zhang Y, Wang Y, Zuo S, Shen Y, et al. Prostaglandin E(2) promotes hepatic bile acid synthesis by an E prostanoid receptor 3-mediated hepatocyte nuclear receptor $4 a /$ cholesterol $7 \alpha$-hydroxylase pathway in mice. Hepatology. 2017;65(3):999-1014. doi: 10.1002/hep.28928.

25. Descalzi G, Ikegami D, Ushijima T, Nestler EJ, Zachariou V, Narita M. Epigenetic mechanisms of chronic pain. Trends Neurosci. 2015;38(4):237-46. doi: 10.1016/j. tins.2015.02.001.

26. Pinheiro BG, Silva AS, Souza GE, Figueiredo JG, Cunha 
FQ, Lahlou S, et al. Chemical composition, antinociceptive and anti-inflammatory effects in rodents of the essential oil of Peperomia serpens (Sw.) Loud. J Ethnopharmacol. 2011;138(2):479-86. doi: 10.1016/j.jep.2011.09.037.

27. Liu Q, Chelly JE, Williams JP, Gold MS. Impact of peripheral nerve block with low dose local anesthetics on analgesia and functional outcomes following total knee arthroplasty: a retrospective study. Pain Med. 2015;16(5):998-1006. doi: 10.1111/pme.12652.

28. Tariq MS, Khan AU, Minhas AM, Filho ER, Din ZU, Khan A. Computational and pharmacological investigation of novel 1,5-diaryl-1,4-pentadien-3-one derivatives for analgesic, anti-inflammatory and anticancer potential. Iran J Basic Med Sci. 2019;22(1):72-9. doi: 10.22038/ ijbms.2018.31261.7536.

29. de Lima AB, Santana MB, Cardoso AS, da Silva JK, Maia JG, Carvalho JC, et al. Antinociceptive activity of 1-nitro2-phenylethane, the main component of Aniba canelilla essential oil. Phytomedicine. 2009;16(6-7):555-9. doi: 10.1016/j.phymed.2008.10.007.

30. Santana MF, Quintans-Júnior LJ, Cavalcanti SCH, Oliveira MGB, Guimarães AG, Cunha ES, et al. p-Cymene reduces orofacial nociceptive response in mice. Rev Bras Farmacogn. 2011;21(6):1138-43. doi: 10.1590/s0102$695 \times 2011005000156$.

31. de Souza Siqueira Quintans J, Menezes PP, Santos MR, Bonjardim LR, Almeida JR, Gelain DP, et al. Improvement of p-cymene antinociceptive and anti-inflammatory effects by inclusion in $\beta$-cyclodextrin. Phytomedicine. 2013;20(5):436-40. doi: 10.1016/j.phymed.2012.12.009.

32. Quintans-Júnior LJ, Oliveira MG, Santana MF, Santana
MT, Guimarães AG, Siqueira JS, et al. $\alpha$-Terpineol reduces nociceptive behavior in mice. Pharm Biol. 2011;49(6):5836. doi: 10.3109/13880209.2010.529616.

33. Gazim ZC, Amorim AC, Hovell AM, Rezende CM, Nascimento IA, Ferreira GA, et al. Seasonal variation, chemical composition, and analgesic and antimicrobial activities of the essential oil from leaves of Tetradenia riparia (Hochst.) Codd in southern Brazil. Molecules. 2010;15(8):5509-24. doi: 10.3390/molecules15085509.

34. Radulović NS, Zlatković DB, Randjelović PJ, Stojanović NM, Novaković SB, Akhlaghi H. Chemistry of spices: bornyl 4-methoxybenzoate from Ferula ovina (Boiss.) Boiss. (Apiaceae) induces hyperalgesia in mice. Food Funct. 2013;4(12):1751-8. doi: 10.1039/c3fo60319a.

35. Nuutinen T. Medicinal properties of terpenes found in Cannabis sativa and Humulus lupulus. Eur J Med Chem. 2018;157:198-228. doi: 10.1016/j.ejmech.2018.07.076.

36. Erasto P, Viljoen AM. Limonene-a review: biosynthetic, ecological and pharmacological relevance. Nat Prod Commun. 2008;3(7):1193-202. doi: $10.1177 / 1934578 \times 0800300728$.

37. Paula-Freire LI, Molska GR, Andersen ML, Carlini EL. Ocimum gratissimum essential oil and its isolated compounds (Eugenol and myrcene) reduce neuropathic pain in mice. Planta Med. 2016;82(3):211-6. doi: 10.1055/s0035-1558165.

38. Shah SM, Ullah F, Shah SM, Zahoor M, Sadiq A. Analysis of chemical constituents and antinociceptive potential of essential oil of Teucrium stocksianum bioss collected from the North West of Pakistan. BMC Complement Altern Med. 2012;12:244. doi: 10.1186/1472-6882-12-244. 